\title{
Modeled Karenia brevis accumulation in the vicinity of a coastal nutrient front
}

\author{
Gerald S. Janowitz*, Daniel Kamykowski \\ 1125 Jordan Hall, Department of Marine, Earth \& Atmospheric Sciences, North Carolina State University, \\ Raleigh, North Carolina 27695-8208, USA
}

\begin{abstract}
The alongshore independent distribution of Karenia brevis, a dominant harmful algal bloom dinoflagellate in the Gulf of Mexico, was investigated in a shelf environment using the Expanded Eulerian physical-biological modeling approach. The physical model included an ocean of variable depth with a frontal region at the $25 \mathrm{~m}$ isobath, and moderate upwelling-favorable winds. Nutrients were available from a surface source conceptually associated with outwelling from Florida bays, and from a near bottom offshore source conceptually associated with upwelling or sediment flux. The biological model included physiological rate processes, biochemical quotas, and behavioral responses based on cellular optimization and environmental conditions. The population distribution at the end of a $37 \mathrm{~d}$ simulation was examined. It was found that cells accumulated in the vicinity of the nearshore front. This accumulation began as soon as cells arrived near the front from the offshore boundary. Approximately $70 \%$ of the population was concentrated in the vicinity of the front by the end of the simulation. The trapping mechanism was interpreted to be a combination of fluid advection and swimming behavior. Four additional $37 \mathrm{~d}$ simulations were performed, where: (1) offshore bottom nutrient source was eliminated, (2) wind stress was doubled, (3) inhibition control on swimming behavior was imposed, and (4) chemotaxis control on swimming behavior was eliminated. Comparison of results from the simulations indicated that chemotaxis can play an important role in frontal accumulation.
\end{abstract}

KEY WORDS: Model $\cdot$ Population dynamics $\cdot$ Dinoflagellate $\cdot$ Behavior Resale or republication not permitted without written consent of the publisher

\section{INTRODUCTION}

Coastal fronts formed by wind-driven upwelling, buoyancy plumes related to coastal outwelling, tidal forcing, and topographic features have all been associated with phytoplankton accumulations (Franks 1992a), sometimes designated as 'red tides' or, if toxic, harmful algal blooms (HABs). In many cases, these accumulations are the result of an interaction between the physical flow field around the front and phytoplankton behavior related to sinking or swimming (Franks 1992b). Fronts also appear to play a major role in the development of HABs by the marine dinoflagellate Karenia brevis over the west Florida continental shelf (Tester \& Steidinger 1997, Walsh et al. 2002). $K$. brevis bloom initiation remains obscure, but some evidence suggests that offshore near-bottom populations may contribute to the more obvious coastal nearsurface HAB events often associated with fronts (Tomlinson et al. 2004).

To investigate physical/biological interactions that may stimulate blooms of Karenia brevis, and to expand on possible accumulation mechanisms, we utilized and further developed the extended Eulerian model of biologically- and physically-driven $K$. brevis population dynamics introduced by Janowitz \& Kamykowski (1999). Briefly, the biological component of this previous study focused on parameters of physiology, biochemistry, and behavior of individual cells and populations of $K$. brevis derived largely from laboratory mesocosm results of Kamykowski et al. (1998a). In a 3 d mesocosm experiment, Kamykowski et al. (1998a) 
observed that a $K$. brevis population composed of same age cells undertook variable diel vertical migrations (DVMs), which suggested that parent cells had divided to yield biochemically unequal daughter cells that followed different DVM scenarios.

The physical part of Janowitz \& Kamykowski's (1999) study used an innovative approach that increased the number of independent variables beyond time and position, and thus had the capability of simulating different behaviors of different cells at any particular spatial location. Liu et al. (2001a) further developed the model for Karenia brevis swimming behavior based on cell internal carbon and nitrogen content, and 2 different temporal measures of integrated light exposure, in order to explain laboratory observations reported by Kamykowski et al. (1998a, 1998b). This behavioral model was used to compare the results of cell populations characterized by equal versus unequal daughter cell formation. In unequal cell formation, the 'poorer' daughter received about one-third of the internal stores of nitrogen and carbon of the parent and the 'richer' daughter about two-thirds. Model simulations that allowed for unequal daughter cells, and that made behavior dependent on both intracellular biochemical and physiological state and on extracellular environmental conditions, most closely resembled laboratory observations.

Liu et al. (2001b) used this biological model within the Expanded Eulerian framework to incorporate response to gradients in the external nutrient field representative of the west Florida shelf. The population distribution was explored for a variety of possible nutrient fields that included offshore, mid-shelf and coastal upwellings, a Trichodesmium spp.-released surface nitrogen source associated with multi-nutrient ocean enrichment by atmospheric dust, and a coastal plume. The occurrence, timing, location, duration and intensity of blooms depended on nutrient concentration, input location, and temporal availability. Liu et al. (2002) considered the effect of a simple linear shear on the population distribution in waters of constant depth. The simulations showed that DVM tended to maintain population coherency despite the tendency of current shear to disperse the population; furthermore, the shear contributed to predictable cell cycling within an aggregation. In addition, the distribution of external nutrient sources influenced the horizontal advection, dispersion, and cellular attributes of Karenia brevis using the modeled swimming rules.

Here we studied the distribution of a Karenia brevis population in an Expanded Eulerian context over a continental shelf with variable bottom topography, representative of west Florida under upwellingfavorable winds. This type of wind field transports nearshore, near-surface nutrients seaward and offshore, and near-sediment nutrients onshore, and often results in a nutrient front. The time course of accumulation of a physiologically and behaviorally well described $K$. brevis population from an offshore, nearbottom source area to an inshore, near-surface frontal zone was investigated under different biological and environmental conditions.

\section{METHODS}

Model description. The swimming behavior of each cell was postulated to depend on selected internal cell variables and external fields as described by Liu et al. (2001a,b, 2002). The internal properties affecting swimming behavior were the total internal carbon $\left(\mathrm{C}_{\mathrm{int}}\right)$; the total internal nitrogen $\left(\mathrm{N}_{\mathrm{int}}\right)$; a measure of the PAR levels to which a cell had been exposed to over the preceding several days (E3); and a measure of recent photosynthetically active radiation (PAR) exposure, the cumulative inhibition $\left(\mathrm{H}_{\text {cum }}\right)$. The external fields were PAR values at the location of a particular cell as well as the local nitrogen and nitrogen gradient levels. The swimming rules and associated speeds are given in the appendix of Liu et al. (2001b). In essence, during the day, cells that exceed a specified value of $\mathrm{H}_{\text {cum }}$ swim downwards. For cells with lower values of $\mathrm{H}_{\text {cum }}$ : those cells low in carbon swim upwards seeking higher PAR, while those high in carbon swim upwards only if the vertical nitrogen gradient is upwards and exceeds $0.01 \mu \mathrm{M} \mathrm{m}^{-1}$; for smaller upwards nitrogen gradients or for vanishing or downwards nitrogen gradients, the high carbon cells swim downwards. In the evening, all cells follow this nitrogen seeking strategy.

The dependent variable in the model is an extended concentration

$$
\mathrm{C}\left(x, y, z, t, \mathrm{C}_{\text {int }}, \mathrm{N}_{\text {int }}, \mathrm{E} 3, \mathrm{H}_{\text {cum }}\right)
$$

defined such that

$\mathrm{C}\left(x, y, z, t, \mathrm{C}_{\text {int } 0}, \mathrm{~N}_{\text {int0 }}, \mathrm{E} 3_{0}, \mathrm{H}_{\text {cum } 0}\right) \mathrm{dC}_{\text {int }} \mathrm{dN}_{\text {int }} \mathrm{dE} 3 \mathrm{dH}_{\text {cum }}$

is the number of cells per unit volume at the location $X_{1}$ $y, z$ at time $t$ with $C_{\text {int }}$ values between $C_{\text {into }}$ and $C_{\text {int } 0}+$ $\mathrm{d}_{\text {Cint }}, \mathrm{N}_{\text {int }}$ values between $\mathrm{N}_{\text {int0 }}$ and $\mathrm{N}_{\text {int0 }}+\mathrm{dN}_{\text {int }}$, E3 values between $\mathrm{E} 3_{0}$ and $\mathrm{E} 3_{0}+\mathrm{dE} 3$, and $\mathrm{H}_{\text {cum }}$ values between $\mathrm{H}_{\text {cum } 0}$ and $\mathrm{H}_{\text {cum } 0}+\mathrm{dH}_{\text {cum. }}$. In this study, we considered the distribution of cells over an ocean with variable depth. To handle variable depth we used the 'sigma coordinates' for spatial independent variables:

$$
\mathrm{X}=\mathrm{x}, \mathrm{Y}=\mathrm{y} \text {, and } \sigma=z / h(x, y)
$$

where $h(x, y)$ is the local water depth and $\sigma$ ranges from 0 at the surface to -1 at the bottom. In sigma co- 
ordinates, the equation which governs the concentration becomes:

$$
\begin{aligned}
& \partial(h \mathrm{C}) / \partial t+\partial(u h \mathrm{C}) / \partial X+\partial(v h \mathrm{C}) / \partial Y \\
& +\partial\left(\left(\omega+\mathrm{W}_{\mathrm{s}} / h\right) h \mathrm{C}\right) / \partial \sigma+\partial\left(\mathrm{VC}_{\mathrm{int}} h \mathrm{C}\right) / \partial \mathrm{C}_{\mathrm{int}} \\
& +\partial\left(\mathrm{VN}_{\text {int }} h \mathrm{C}\right) / \delta \mathrm{N}_{\text {int }}+\partial(\mathrm{VE} 3 h \mathrm{C}) / \partial \mathrm{E} 3 \\
& +\partial\left(\mathrm{VH}_{\text {cum }} h \mathrm{C}\right) / \partial \mathrm{H}_{\mathrm{cum}}=\left(\mathrm{K}_{\mathrm{v}} / h^{2}\right) \partial^{2}(h \mathrm{C}) / \partial \sigma^{2} \\
& + \text { Gains due to reproduction }
\end{aligned}
$$

In Eq. (1), $u$ and $v$ are horizontal fluid velocities, $\omega$ is the sigma velocity $(\omega=[w-\sigma(u \partial h / \partial x+v \partial h / \partial y)] / h), h$ is the depth $h(x, y), \mathrm{W}_{\mathrm{s}}$ is vertical swimming speed, $\mathrm{VC}_{\mathrm{int}}$ is the net time rate of increase in $\mathrm{C}_{\text {int }}$ due to photosynthesis, $\mathrm{VN}_{\text {int }}$ is the time rate of increase in $\mathrm{N}_{\text {int }}$ due to nitrogen uptake, VE3 is the time rate of change of E3, $\mathrm{VH}_{\text {cum }}$ is the time rate of change of $\mathrm{H}_{\text {cum }}$, and $\mathrm{K}_{\mathrm{v}}$ is the (constant) turbulent mixing coefficient. Equations describing the internal 'velocities' are given in the appendix of Liu et al. (2001b). Reproduction was assumed to occur between 03:00 and 06:00 $\mathrm{h}$ for those cells with a full quota of $\mathrm{C}_{\text {int }}$ and $\mathrm{N}_{\text {int }}$ that produced one daughter with minimum values of $C_{\text {int }}$ and $N_{\text {int }}$ and another daughter with the remaining (larger) share of these variables. The total cell concentration at a point in physical space (i.e. number of cells per unit volume) was simply the integral of the cell concentration $\mathrm{C}(x, y$, $z, t, \mathrm{C}_{\text {int }}, \mathrm{N}_{\text {int }}, \mathrm{E} 3, \mathrm{H}_{\text {cum }}$ ) over the range of all internal variables. Eq. (1) is an extension of the previous model described by Janowitz \& Kamykowski (1999) to a variable depth ocean. Computationally, the range of each variable was subdivided into a number of contiguous intervals, and concentrations at discrete values of the variables at the next time step were computed via upwind differencing in the advection terms and by an explicit scheme for the turbulent diffusion term.

We note some shortcomings associated with the above numerical procedures. Using the values of parameters specified below, the explicit diffusion scheme would become unstable in waters shallower than $8.5 \mathrm{~m}$. However, in our simulations, cells did not reach these shallow regions and the explicit scheme was stable throughout our computational domain. A doubling of the poorly known turbulent mixing coefficient would increase the maximum depth for numerical instability and the thickness of the top and bottom layers of high cell concentration by about $40 \%$, but otherwise would not significantly affect population development. The upwind differencing scheme, along with other advective schemes, produces numerical dispersion. In the vertical this would be equivalent to about a $25 \%$ increase in the turbulent mixing coefficient and would have little effect on population development. Under maximum nutrient uptake and carbon production, we estimated that numerical dispersion in these variables would increase the time necessary for a cohort of cells to fill internal quotas by about a day. Given the narrow reproductive window, about one-third of the cohort would reproduce one day early, about a third on the day expected without dispersion, and about a third one day late. This tendency smoothed out reproductive gains but should not have significantly affected population development. Under less than maximum uptake, the estimate of the numerical dispersion coefficient decreases.

Because we performed $37 \mathrm{~d}$ simulations, we made 1 simplification to the model to decrease computation time. The value of $\mathrm{H}_{\text {cum }}$ for a cell is very nearly the value of the instantaneous inhibition experienced by the cell $1 \mathrm{~h}$ earlier. Further, since the value of instantaneous inhibition is based on the instantaneous PAR value and the value of the inhibition threshold, which is based on the value of $\mathrm{E} 3$, the value of $\mathrm{H}_{\text {cum }}$ at a point in space is taken to be the value of instantaneous inhibition based on PAR at that point $1 \mathrm{~h}$ earlier and the current value of E3. This eliminates $H_{\text {cum }}$ as an independent variable, since all cells at a given point in space and a given value of E3 have the same value of $\mathrm{H}_{\text {cum }}$. We can thus drop the final term on the left hand side of Eq. (1). We noted that $\mathrm{H}_{\text {cum }}$ was still a very important parameter in the equation describing net photosynthesis; however, as it was taken to be a specified function of PAR and E3, it was not an independent variable as the internal state was completely described by $\mathrm{C}_{\text {int }}, \mathrm{N}_{\text {int }}$, and E3.

One other change was made to the swimming rules, based on recent evidence. In the previous studies (e.g. Liu et al. 2001b), the cell was postulated to swim downwards during the day when the value of $\mathrm{H}_{\text {cum }}$ exceeded 0.8 . Observed accumulation of natural Karenia brevis cells at the air-surface interface during intense midday sunlight indicates that this is not necessarily the case, and that $\mathrm{H}_{\text {cum }}$ may have no impact on swimming direction. On first glance this is counterintuitive as high values of $\mathrm{H}_{\text {cum }}$ lead to low photosynthesis rates on that day. However, continuing exposure to high light implied by this lack of $\mathrm{H}_{\text {cum }}$ control will increase a cell's value of E3 and thus its inhibition threshold, and will condition the cell to be more productive in carbon under higher light on the following days. In any case, based on field observations, we dropped the control of $\mathrm{H}_{\text {cum }}$ on swimming behavior in this study.

External fields. The distribution of the population of cells was determined in large part by the current field, the PAR field, and the nutrient field. We first discuss the currents. We considered a bottom topography with a depth that was unchanging in the along-shore direction and decreased linearly with distance towards the coast. The steady wind field was uniform in space and in the along-shore direction with shallow waters to the left of the wind, a classical northern hemisphere upwelling scenario (Fig. 1). The currents and sea 
surface slope thus did not change in the alongshore direction. The equations which governed flow under a constant eddy viscosity assumption were as follows:

$$
\begin{gathered}
-f v=-g d \eta / d x+A_{v} \partial^{2} u / \partial z^{2} \\
f u=A_{v} \partial^{2} v / \partial z^{2} \\
\partial u / \partial x+\partial w / \partial z=0
\end{gathered}
$$

In Eq. (2), $f$ is the Coriolis parameter, $\mathrm{A}_{\mathrm{v}}$ the constant eddy viscosity, and $d \eta / d x$ the sea surface slope in the offshore direction.

An analytical solution to the horizontal momentum equations was obtained under the conditions where:

$$
\begin{gathered}
u=0, v=0 \text { at } z=-h \\
\text { and } \mathrm{A}_{\mathrm{v}} \partial u / \partial z=0, \mathrm{~A}_{\mathrm{v}} \partial v / \partial z=\tau_{\mathrm{y}} / \rho \text { at } z=0
\end{gathered}
$$

When we impose the condition that net onshore transport (which determines the sea surface slope $d \eta / d x$ ) vanishes, the solution for horizontal velocity is completed. The continuity in Eq. (2) can then be used to compute $w$ and hence $\omega$. The horizontal onshore velocity $u$ at 40,25, and $10 \mathrm{~m}$ depth is shown in Fig. 2 for a specified kinematic stress $\left(\tau_{\mathrm{y}} / \rho\right)$ of $-0.4 \times 10^{-4} \mathrm{~m}^{2} \mathrm{~s}^{-2}$. Note that maximum speeds at $25 \mathrm{~m}$ water depth are only slightly less than those at $40 \mathrm{~m}$, while maximum speeds at $10 \mathrm{~m}$ are only one-tenth of those at $40 \mathrm{~m}$ depth.

The surface PAR was taken to vary sinusoidally with time over a $12 \mathrm{~h}$ day, with sunrise at 06:00 $\mathrm{h}$ and sunset at $18: 00 \mathrm{~h}$ and a maximum at $12: 00 \mathrm{~h}$ of $1500 \mu \mathrm{mol}$ quanta $\mathrm{m}^{-2} \mathrm{~s}^{-1}$. Negative nocturnal values were set

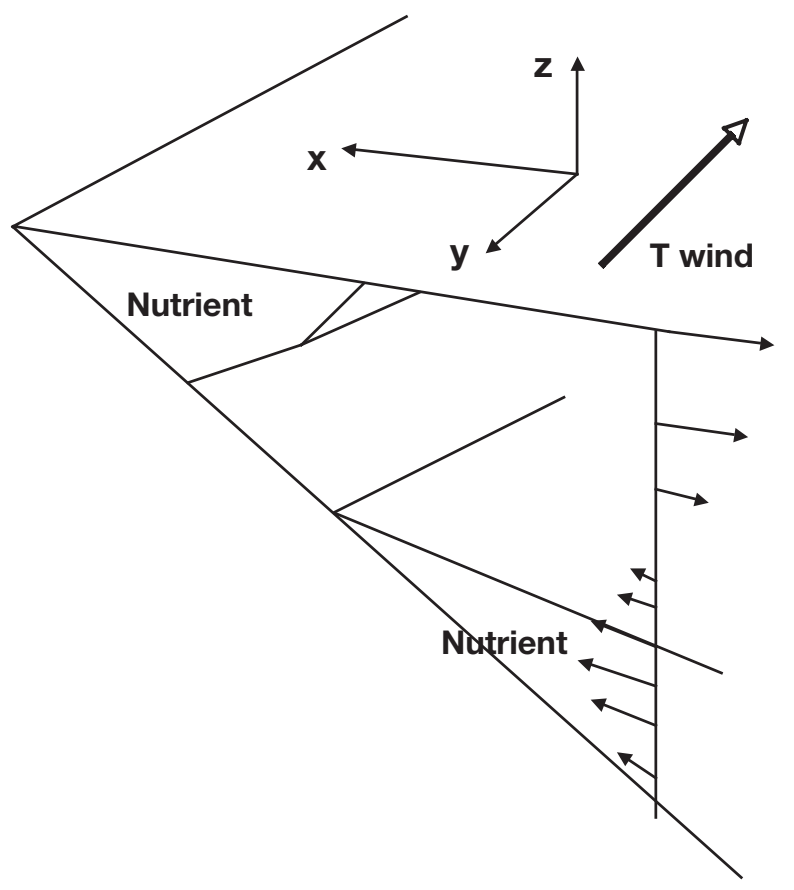

Fig. 1. Upwelling scenario showing coordinate system, wind direction, nutrient source location, and onshore velocity to 0. Decay with depth was as discussed in Liu et al. (2001b). The nutrient field was composed of 2 nitrogen-related components: a surface plume driven outwards from the coast by offshore-flowing surface currents, and a bottom source driven inwards toward the coast by onshore-flowing bottom currents (Fig. 3). The nutrient fields were specified to remain unchanged with time over the course of our simulations. In the absence of re-supply, our calculations demonstrated that about $15 \%$ of nutrients will be consumed by the population and could be easily re-supplied. Both sur-
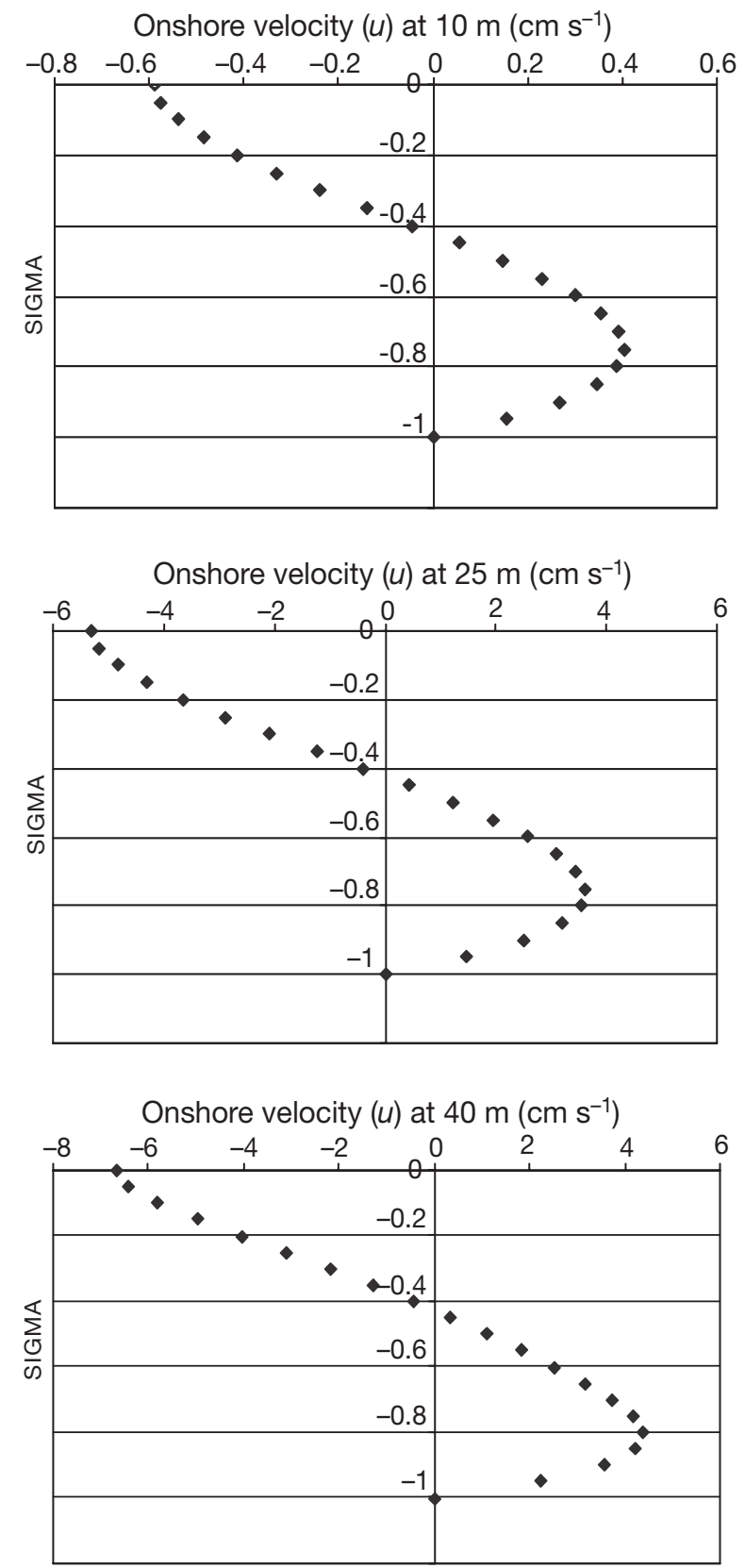

Fig. 2. Onshore velocity at 3 water depths 
face and bottom components conceptually included any form of inorganic or organic nitrogen that Karenia brevis is capable of utilizing. Both components terminated near a depth of $25 \mathrm{~m}$. In the following expressions, $h$ and $z$ are in $\mathrm{m}$.

The surface nitrogen component (NS: $\mu \mathrm{M})$ is specified as:

$$
\mathrm{NS}=1.25(\{1+\tanh [2(25-h)]\} / 2) \mathrm{e}^{z / 10}
$$

and the bottom nitrogen component (NB: $\mu \mathrm{M})$ as

$$
\mathrm{NB}=5(\{1+\tanh [2(h-25)]\} / 2) \mathrm{e}^{-(h+z)}
$$

Although the bottom source is most readily interpreted as an upwelling plume moving along the bottom, it also conceptually represents seaward nitrogen flux across the sediment-sea interface. Possible sources of these sediment-derived nutrients are the settled biomass from previous diatom blooms in response to an upwelling or cyanobacteria (or more specifically Trichodesmium spp.) blooms resulting from $\mathrm{N}$-fixation events in response to the arrival of iron-rich Saharan dust (Walsh et al. 2001). In offshore waters, the bottom nitrogen component from a sub-euphotic zone upwelling plume or from the sediments is uniquely available to dinoflagellates like Karenia brevis, because their DVM and nitrogen uptake characteristics allow these cells to utilize nutrient resources below the bottom of the normal euphotic zone where low light can limit less motile phytoplankton (Sinclair 2005). After filling their nitrogen pools near the sediment interface, these dinoflagellates can then swim up to the lower part of the euphotic zone to access light in support of net photosynthesis.

Parameter values and initial and boundary conditions. The flow was driven by a wind with a kinematic stress $\left(\tau_{\mathrm{y}} / \rho\right)$ of $-0.4 \times 10^{-4} \mathrm{~m}^{2} \mathrm{~s}^{-2}$, a Coriolis parameter of $0.66 \times 10^{-4} \mathrm{~s}^{-1}$, and a bottom slope of $5 \times$ $10^{-4}$ - values characteristic of the west south Florida shelf (Yang \& Weisberg 1999). An eddy viscosity following the formula $\left(\tau_{\mathrm{y}} / \rho\right) 200 f$ of $30 \times 10^{-4} \mathrm{~m}^{2} \mathrm{~s}^{-1}$ was utilized. A smaller value of $5 \times 10^{-4} \mathrm{~m}^{2} \mathrm{~s}^{-1}$ was utilized for $\mathrm{K}_{\mathrm{v}}$.

In our model runs, ranges of $\sigma, C_{\text {int }}$, and $N_{\text {int }}$ were divided into 20 equal intervals, a step size of $1 \mathrm{~km}$ was taken into the onshore variable $\mathrm{X}$, the $\mathrm{E} 3$ range was divided into 5 intervals, and a time step of 3 min was utilized. Concentrations were thus calculated at an average of approximately $1.24 \times 10^{6}$ grid points at each time step. To save computational time, the computational domain was extended onshore with increasing time with the maximum onshore velocity; the domain was only a few kilometers early in the computation when cells had moved only a short distance, but by the end of the computation the grid extended $60 \mathrm{~km}$ inshore of the $40 \mathrm{~m}$ isobath. The number of grid points

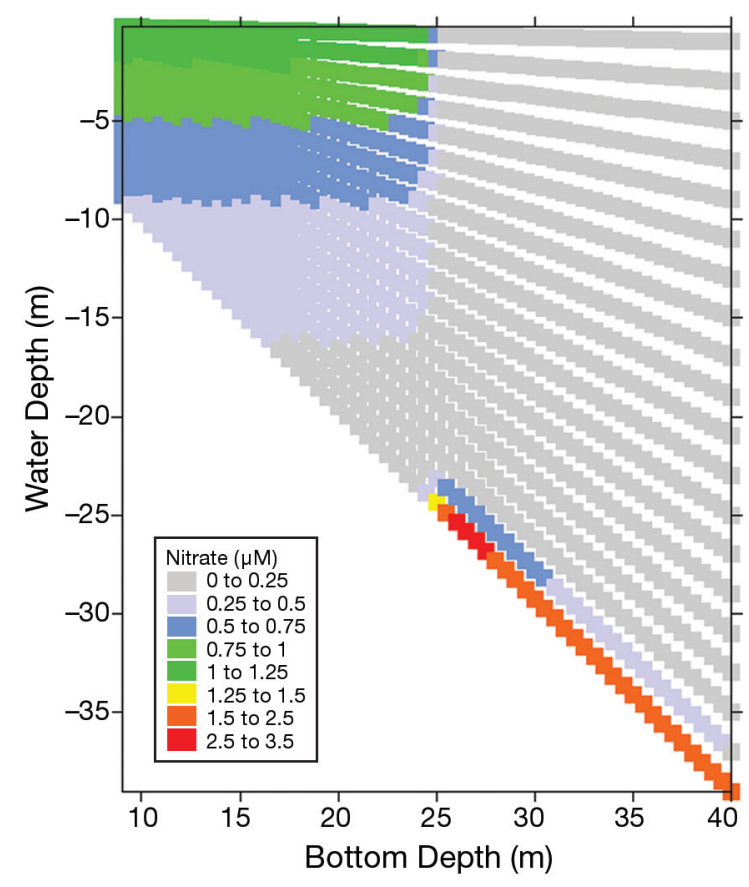

Fig. 3. Nutrient field for the primary simulation

at which it was necessary to calculate concentration ranged from $1.2 \times 10^{5}$ at the start of the simulation to $2.48 \times 10^{6}$ at the end.

When a nutrient front is established, there may well be cells in the vicinity of the front that contribute to the structure of a population. However, to best determine the role of fronts in bloom initiation, we chose to start with no cells initially present onshore of the $40 \mathrm{~m}$ isobath. From the start of the calculation, we specified a fixed cell concentration of $1 \mathrm{cell} \mathrm{ml}^{-1}$ (a typical background concentration; Tester \& Steidinger 1997), on the inflow portion (lowest $22 \mathrm{~m}$ ) of the water column at the $40 \mathrm{~m}$ isobath. Half of these cells were poor daughter cells with the minimum $\mathrm{C}_{\text {int }}$ and $\mathrm{N}_{\text {int }}$ values of 36 pmol C cell ${ }^{-1}$ and 6.3 pmol $\mathrm{N}$ cell ${ }^{-1}$, respectively, and half were rich daughter cells with $C_{\text {int }}$ and $N_{\text {int }}$ values of 54 pmol C cell ${ }^{-1}$ and $17 \mathrm{pmol} \mathrm{N}$ cell $^{-1}$, respectively. Present evidence suggests that differences in carbon and nitrogen content among cells can result either from daughter cells unequally sharing parental carbon and nitrogen resources (Kamykowski et al. 1998a), or from physiological and biochemical changes related to differential light (Evens et al. 2001) and nitrogen exposure (Sinclair 2005). Since boundary concentration, water depth, and velocity are independent of the alongshore variable $\mathrm{Y}$, the concentration will also be independent of this variable: therefore, we dropped the third term on the left hand side of Eq. (1). Development of the cell distribution in waters shallower than $40 \mathrm{~m}$ were thus described. 


\section{RESULTS AND DISCUSSION}

Using the values of external fields and other parameters discussed above, we performed our first simulation (the primary simulation) which best simulated average physical conditions on the west Florida shelf. To test the robustness of these results and their sensitivity to changes in the external fields and swimming 'rules', we then performed 4 secondary simulations. All simulations were run for $37 \mathrm{~d}$ and $2 \mathrm{~h}$.

\section{Primary simulation}

In the $37 \mathrm{~d}, 2 \mathrm{~h}$ simulation, it was possible for cells to reach the $9 \mathrm{~m}$ isobath. A sufficient number of cells flowed into the region and reproduced there to yield an average total concentration over the entire domain of over 2.3 cells ml-1, more than twice background concentration. Our results indicated that this average value was somewhat misleading. In fact, less than 0.1 cells ml ${ }^{-1}$ were present in waters of depths of $16 \mathrm{~m}$ or less.

Over the course of the simulation, $2.025 \times 10^{12}$ cells flowed into the region in the bottom $22 \mathrm{~m}$ and $0.582 \times$ $10^{12}$ cells flowed offshore in the top $18 \mathrm{~m}$ across the $40 \mathrm{~m}$ isobath, leading to a net inflow of $1.443 \times 10^{12}$ cells. Since the total population onshore of the $40 \mathrm{~m}$ isobath was calculated at $5.896 \times 10^{12}$ cells, $4.453 \times 10^{12}$ cells were created by reproduction in the region.

In Fig. 4, the concentration fields in cells $\mathrm{ml}^{-1}$ at $06: 00,12: 00,18: 00$ and $24: 00 \mathrm{~h}$ on the 37 th day of the run are shown. Since reproduction was assumed to occur between 03:00 and 06:00 $\mathrm{h}$, the total population in the region varied only slightly due to a small (less than $1 \%$ ) net inflow during this period. We observed that the population was clustered in the vicinity of the front, with approximately $70 \%$ of the population inshore of the $28 \mathrm{~m}$ isobath and offshore of $22 \mathrm{~m}$ depth (the frontal region). The total concentration at the surface reached a maximum at $25 \mathrm{~m}$ depth, as that location received upward-swimming cells from further onshore. In deeper waters, the nitrogen gradient caused a loss of cells from the surface. The surface total concentration at this depth varied from 23.2 cells ml ${ }^{-1}$ at $06: 00 \mathrm{~h}$ to a maximum of 30.8 cells ml ${ }^{-1}$ at $12: 00 \mathrm{~h}$, and decreased to 29.5 cells ml $^{-1}$ at $18: 00 \mathrm{~h}$ and to 27.9 cells $\mathrm{ml}^{-1}$ at $24: 00 \mathrm{~h}$. At 06:00 $\mathrm{h}$ the next day the concentration was 25.5 cells ml- ${ }^{-1}$, a slightly higher value than the preceding sunrise due to reproduction that occurred between 03:00 and 06:00 h. The bottom concentration reached a maximum at $25.5 \mathrm{~m}$ depth, as cells from further offshore were attracted downwards by the nitrogen gradient and attracted upwards by the surface nitrogen plume further onshore of this depth.
The maximum bottom concentrations began at 30.5 cells $\mathrm{ml}^{-1}$ at $06: 00 \mathrm{~h}$, dropped to $29.6 \mathrm{cells} \mathrm{ml}^{-1}$ at $12: 00 \mathrm{~h}$, rose to 33.15 cells ml $^{-1}$ at 18:00 $\mathrm{h}$, and reached a maximum of 35.8 cells ml $^{-1}$ at 24:00 h. At 06:00 h, the concentration of $33.2 \mathrm{cell} \mathrm{ml}^{-1}$ was somewhat higher than the preceding day again due to reproduction.

The frontal area is a highly reproductive region. Between 24:00 and 06:00 $\mathrm{h}$ the following day, the total population in the frontal region increased by $10 \%$ while the population elsewhere increased by only $3 \%$. It takes about $22 \mathrm{~d}$ for the pattern of accumulation in the frontal area to occur, about $1 \mathrm{wk}$ after cells arrive in quantity from the computational boundary. Thereafter, the number of cells in the domain continued to increase but the pattern changed little: i.e., the ratio of the total concentration at a point in the frontal region to the maximum total concentration in the domain at a given time of day did not vary much from Day 22 to Day 37. However, the maximum total concentration did increase from 9 cells ml- ${ }^{-1}$ on Day 22 to 36 cells ml ${ }^{-1}$ on Day 37.

The accumulation pattern can be understood in terms of fluid advection and postulated swimming behavior. During the day, the onshore-flowing rich daughter cells near the computational boundary were advected onshore and initially swam upwards; they then quickly approached the high carbon limit and swam downwards towards the high nitrogen bottom region and remained in the onshore-flowing bottom portion of the water column. The poor daughter cells swam upwards towards the offshore-flowing upper reaches of the water column. Some were advected out of the computational region, but some reached the high carbon limit and then swam downwards and moved onshore near the bottom again. Once the onshore-flowing cells reached the nutrient front during the day, high carbon cells swam upwards as the nitrogen gradient was now upwards and exceeded $0.01 \mathrm{\mu M} \mathrm{m}^{-1}$, and low carbon cells also swam upwards seeking higher PAR values. During the night, all cells onshore of the front swam upwards following the upwards nitrogen gradient, and all cells offshore of the front swam downwards following the downwards nitrogen gradient. Thus bottom onshore-flowing waters were depleted of cells onshore of the front. Surface waters then became high in cells onshore of the front, and flowed offshore.

Once they passed the front, high carbon cells swam downwards following the downwards nitrogen gradient and then flowed onshore again towards the front. Low carbon cells that obtained high carbon levels swam downwards and returned towards the front, while some low carbon cells that did not reach the high carbon limit remained in the offshore-flowing surface waters and were lost to the computational region. The 

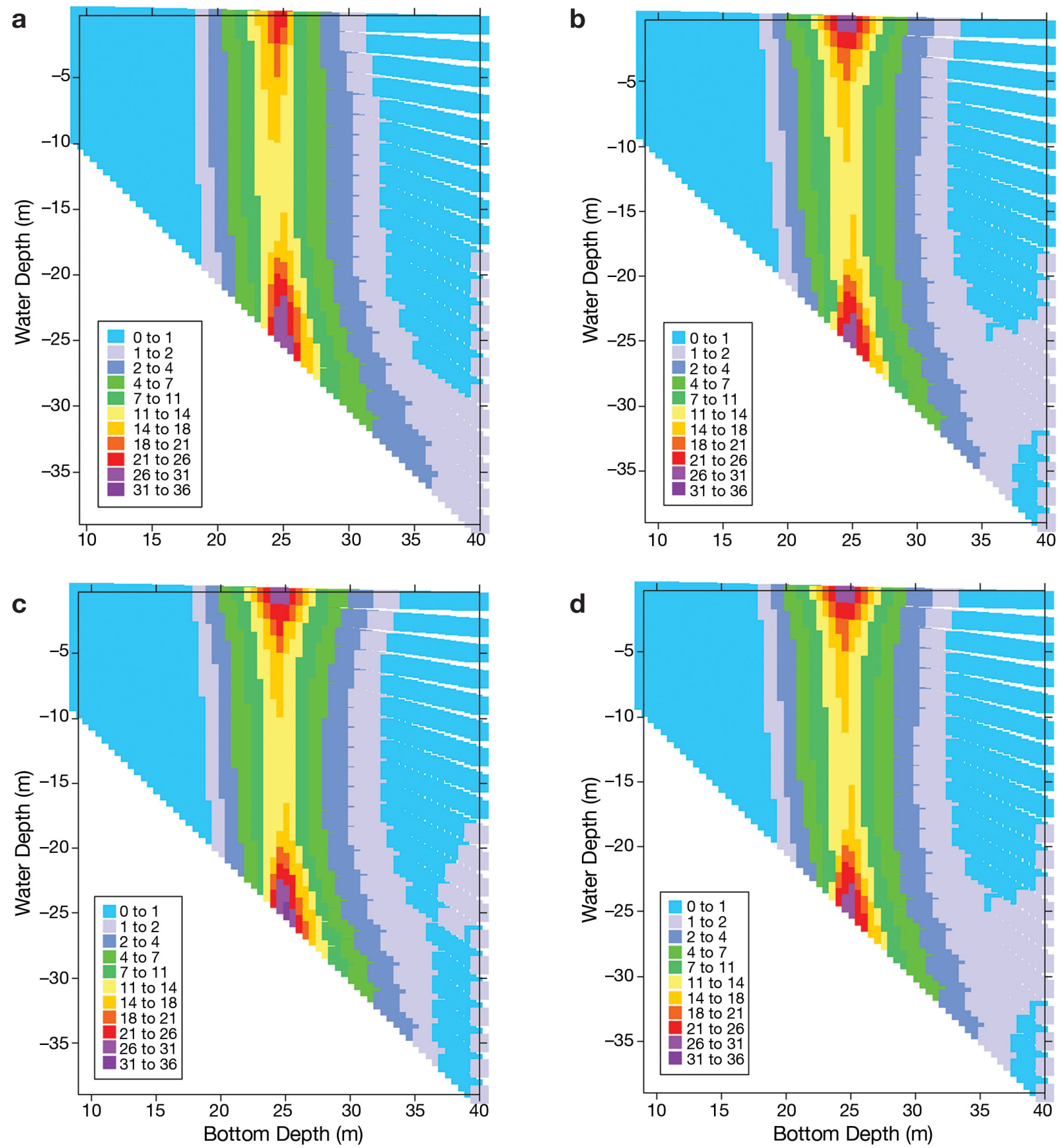

Fig. 4. Total concentration of cells (no. of cells ml ${ }^{-1}$ ) at (a) 06:00 h, $36 \mathrm{~d}$ and $2 \mathrm{~h}$, (b) 12:00 h, $36 \mathrm{~d}$ and $8 \mathrm{~h}$, (c) 06:00 h, $36 \mathrm{~d}$ and $14 \mathrm{~h}$, and (d) 24:00 h, $36 \mathrm{~d}$ and $20 \mathrm{~h}$ after initiation of the primary simulation

daytime scenario is depicted in Fig. 5. In Fig. 5, the trajectories of low carbon cells ( 36 to $54 \mathrm{pmol} \mathrm{C} \mathrm{cell}{ }^{-1}$ ) are denoted by the dotted line, and the trajectories of intermediate carbon cells (54 to $68 \mathrm{pmol} \mathrm{C}$ cell $^{-1}$ ) are denoted by the dashed line; both cell types swam upwards seeking higher PAR. The trajectory of high carbon cells ( $>68 \mathrm{pmol} \mathrm{C}$ cell $^{-1}$ ) is denoted by the solid line, and they swam along the nitrogen gradient. Low carbon cells could become intermediate carbon cells, and some intermediate carbon cells could become high carbon cells. Most intermediate carbon cells could become high carbon cells in $1 \mathrm{~d}$. The horizontal arrows in Fig. 5 denote the direction of currents. To test the explanation of trapping, and to quantify the effects of 

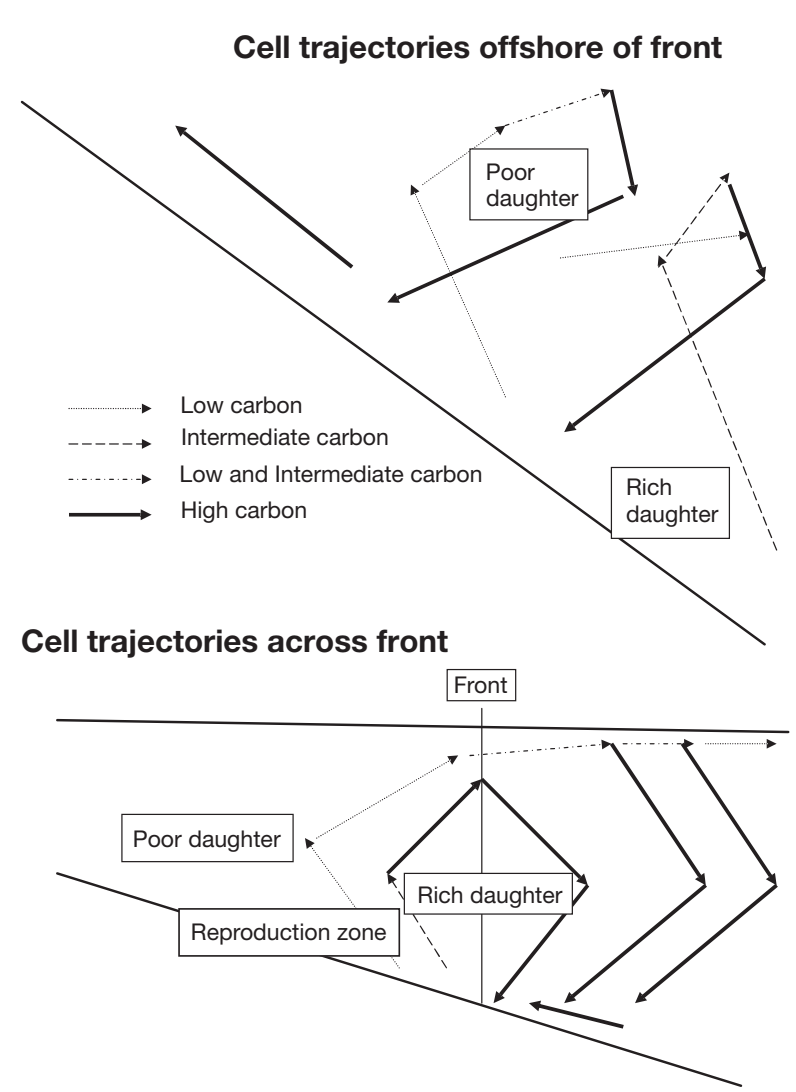

Fig. 5. Frontal trapping scenario due to onshore-offshore fluid advection and vertical swimming behavior

changing parameters, we performed 4 additional simulations (i.e. secondary simulations). In the following discussion where numerical values for the results of a simulation are given, values for the primary simulation are given in parentheses.

\section{Secondary simulations}

\section{Eliminating the bottom nutrient source}

The frontal trapping scenario did not require the presence of a bottom nutrient source, but simply the absence of a sufficiently strong upwards nutrient gradient offshore of the surface plume. To determine the role of the bottom nutrient source, we performed a second simulation. We set the bottom source NB to 0 and again performed a $37 \mathrm{~d} 2 \mathrm{~h}$ simulation. As expected, the pattern of accumulation in the vicinity of the front was nearly the same as in the first simulation, because a bottom source was not needed to produce trapping but rather just an absence of an upwards nutrient gradient offshore of the surface plume. Fig. 6 shows the total cell concentration field at 12:00 h of Day 37, which can be compared to Fig. $4 \mathrm{~b}$. At the end of the simula- tion, the total population was $2.644 \times 10^{12}\left(5.896 \times 10^{12}\right)$ cells. The 'no bottom source' value was about 0.46 of the value of the primary simulation. However, when we subtracted the net number of cells entering the domain to obtain the number of cells reproduced there, we found that the no bottom source number of $1.142 \times$ $10^{12}\left(4.453 \times 10^{12}\right)$ cells was only 0.26 times the value of the primary simulation. The percent of the population in the frontal region (22 to $28 \mathrm{~m}$ ) was $65 \%$ (70\%). At 24:00 and 06:00 h of Day 37, the population onshore of $28 \mathrm{~m}$ increased by $0.13 \times 10^{12}\left(0.41 \times 10^{12}\right)$ cells. Thus, the presence of the bottom source played a significant role in population size once cells were trapped near the front.

\section{Doubling the wind stress}

To test the role of an important environmental parameter we performed another simulation. We returned to all the parametric values of the primary simulation except for wind stress. We changed the value of the alongshore kinematic wind stress from $-0.4 \times$ $10^{-4} \mathrm{~m}^{2} \mathrm{~s}^{-2}$ to $-0.8 \times 10^{-4} \mathrm{~m}^{2} \mathrm{~s}^{-2}$, which corresponded to a change in wind speed from about $5 \mathrm{~m} \mathrm{~s}^{-1}$ to about $7 \mathrm{~m} \mathrm{~s}^{-1}$. This increase of the wind stress doubles the value of eddy viscosity, the surface offshore flow at water depths greater than $60 \mathrm{~m}$, and the counterbalancing pressure gradient-driven onshore bottom transport. It also increases the value of Ekman layer thicknesses and deep water velocities by a factor of 1.414. As Fig. 2 demonstrates, the bottom and surface Ekman layers overlap even within the primary simulation and would overlap even more in this case, so we did not expect a large increase in off- and onshore fluxes.

When in deep water, we expected an increase in onshore speeds with an increase in the magnitude of wind stress; in shallower waters, we expected the reverse to be true. An increase in the dominant frictional forces in shallow water (vis-a-vis the Coriolis force) would result in the flow being more alongshore and less onshore. Numerical calculations of the maximum onshore velocity for the 2 wind stress cases indicated that speeds were larger for the larger magnitude stress in waters deeper than $32 \mathrm{~m}$, and weaker in shallower waters. A calculation of minimum travel times from the $40 \mathrm{~m}$ isobath to the $25 \mathrm{~m}$ isobath (the front) indicated that cells could reach the front $2 \mathrm{~d}$ earlier for the higher stress case, but at the end of the $37 \mathrm{~d}$ simulation would only reach the 12 (9) $\mathrm{m}$ isobath. However, with higher speeds at $40 \mathrm{~m}$, we expected more cells to enter the domain, more reproduction to occur and a larger population to develop.

Fig. 7 shows the total concentration field at 12:00 h on Day 37, which can be compared with Fig. 4b. Trap- 
ping in the vicinity of the front was clear: $75 \%(70 \%)$ of the population was located between the 22 and $28 \mathrm{~m}$ isobaths. The maximum concentration at the surface at $25 \mathrm{~m}$ was $47.3(30.8)$ cells $\mathrm{ml}^{-1}$. The total population at the end of the simulation was $7287 \times 10^{12}\left(5.896 \times 10^{12}\right)$ cells. The net number of cells entering the domain was $1.794 \times 10^{12}\left(1.443 \times 10^{12}\right)$, and the net number of cells reproduced was $5.493 \times 10^{12}\left(4.453 \times 10^{12}\right)$. It was clear that higher wind stresses positively impacted on population and cell density.

\section{Imposing inhibition control on swimming behavior}

As mentioned earlier, we eliminated the control of $\mathrm{H}_{\text {cum }}$ on swimming behavior. In earlier studies (e.g. Janowitz \& Kamykowski 1999, Liu et al. 2001b), all cells swim downwards when $\mathrm{H}_{\text {cum }}$ reaches 0.8 . Since carbon production decreases as $\mathrm{H}_{\text {cum }}$ increases, the lack of $\mathrm{H}_{\text {cum }}$ control should decrease carbon production and delay reproduction, a counterintuitive result. This would be partially offset by a slight increase in the E3 value of a cell as it is exposed to higher light on that day without $\mathrm{H}_{\text {cum }}$ swimming control; slightly higher values of E3 would result in slightly higher inhibition thresholds on subsequent days in addition to somewhat higher carbon production. The $\mathrm{H}_{\text {cum }}$ swimming

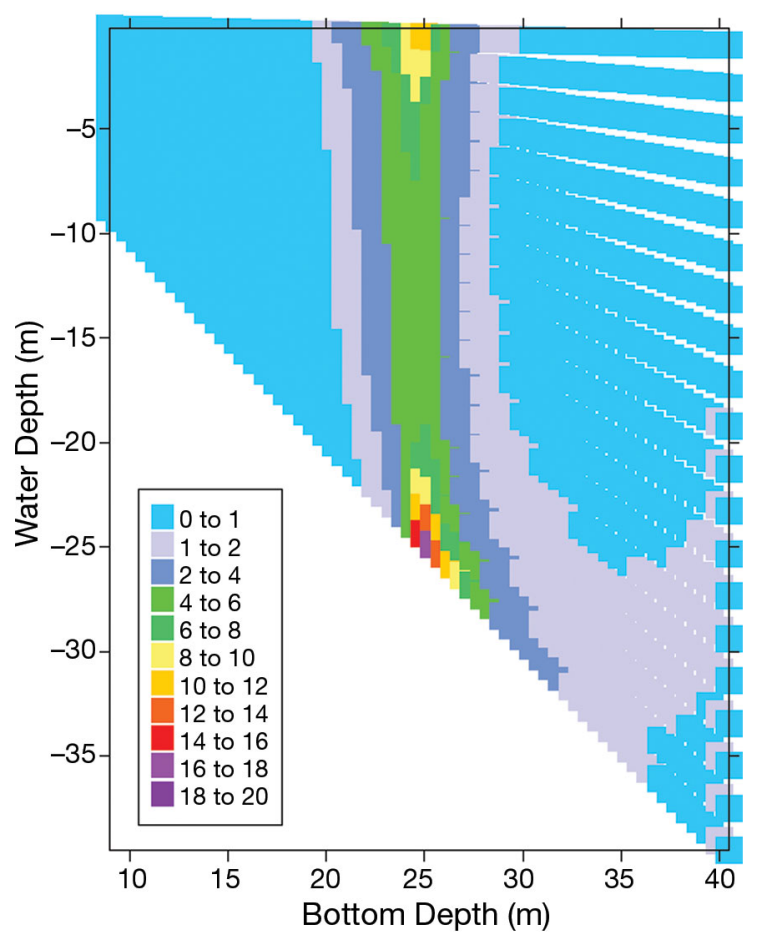

Fig. 6. Total concentration of cells (no. of cells $\mathrm{ml}^{-1}$ ) at 12:00 h, $36 \mathrm{~d}$ and $8 \mathrm{~h}$ after initiation of secondary simulation - elimination of bottom nutrient source control would also tend to keep cells further down in the water column where they would be less susceptible to offshore motion.

We performed a fourth simulation where the $\mathrm{H}_{\text {cum }}$ swimming control was imposed but all other factors remained the same as in the primary simulation. The population was again concentrated near the front. Fig. 8 shows the total concentration at 12:00 h on Day 37. At the end of the run, a total population of $7.073 \times 10^{12}$ $\left(5.895 \times 10^{12}\right)$ cells existed in the region, a $20 \%$ increase in total population relative to the primary simulation. There was a slight increase in the net inflow of cells, $1.521 \times 10^{12}\left(1.443 \times 10^{12}\right)$, because net outflow was decreased somewhat due to the fact that inhibition control on swimming kept cells deeper in the water column. The net reproduction of cells was also higher, $5.552 \times 10^{12}\left(4.453 \times 10^{12}\right)$, an increase of $25 \%$. The percent of the population in the frontal region (22 to $28 \mathrm{~m})$ was $67 \%(70 \%)$, and the maximum surface con-

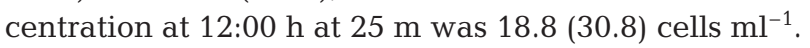
We noted that inhibition control produced a subsurface maximum at $12: 00 \mathrm{~h}$, and that the concentration in the lower $90 \%$ of the water column at $25 \mathrm{~m}$ depth was greater than in the primary simulation. Thus, we observed that removal of $\mathrm{H}_{\text {cum }}$ control on swimming did have a negative impact on the population, but that the impact was not large.

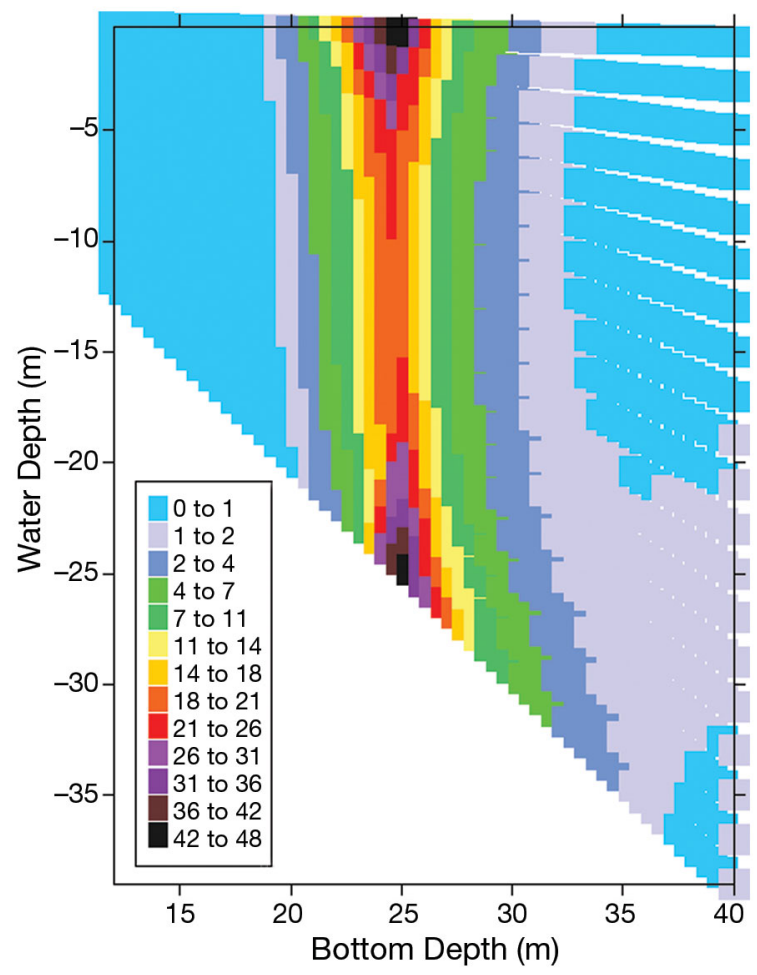

Fig. 7. Total concentration of cells (no. of cells ml-1) at 12:00 h, $36 \mathrm{~d}$ and $8 \mathrm{~h}$ after initiation of secondary simulation - doubled wind stress 


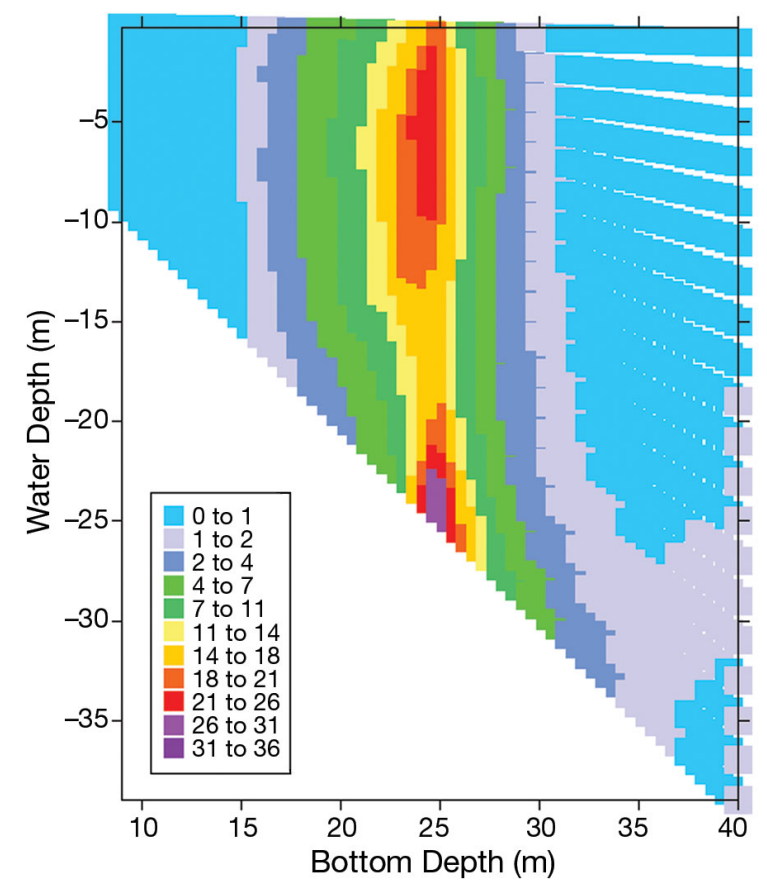

Fig. 8. Total concentration of cells (no. of cells ml-1) at 12:00 h, $36 \mathrm{~d}$ and $8 \mathrm{~h}$ after initiation of secondary simulation - inhibition control on swimming behavior imposed

\section{Eliminating chemotaxis control on swimming behavior}

The preceding 4 simulations all demonstrated cell accumulation in the vicinity of the front. We have postulated that chemotaxis control on swimming behavior, i.e. that high carbon cells during the day and all cells at night swim in the direction of the nutrient gradient, plays a major role in this accumulation. To test this assertion, we performed a final simulation where chemotaxis control was removed. We specified that high carbon cells during the day and all cells at night move downwards. This was the rule utilized in Liu et al. (2001a) - a simulation in a uniform nutrient environment. Fig. 9 shows the total concentration field at 12:00 h on Day 37. Cells were no longer concentrated at the front, and $50 \%(7 \%)$ of the cells were inshore of the $22 \mathrm{~m}$ isobath. The maximum surface concentration of 15.9 (30.8) cells ml ${ }^{-1}$ was located at 19 (25) m water depth. The weak surface maximum disappeared after 18:00 $\mathrm{h}$, unlike preceding simulations, as low carbon cells swam downward. The lack of concentration near the front was not surprising, as swimming behavior no longer changed across the front with the direction of the nutrient gradient. At the end of the simulation, $6.9268 \times 10^{12}\left(5.895 \times 10^{12}\right)$ cells existed in the region. The net number of cells entering the region $(1.449 \times$ $\left.10^{12}\left[1.443 \times 10^{12}\right]\right)$ was nearly identical to the primary simulation, as swimming directions were the same in

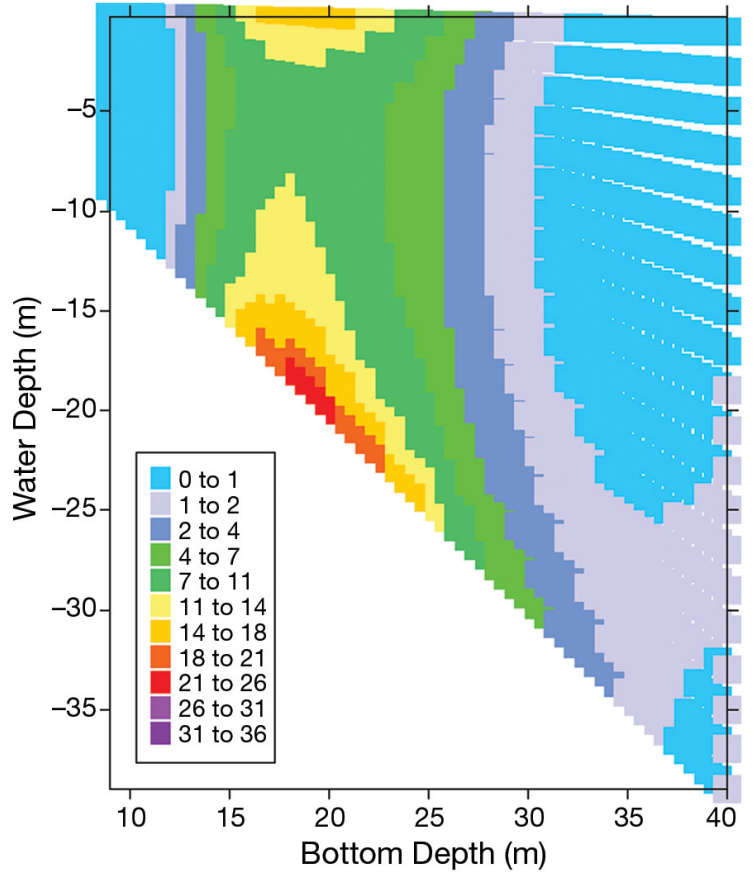

Fig. 9. Total concentration of cells (no. of cells ml $\mathrm{l}^{-1}$ ) at 12:00 h, $36 \mathrm{~d}$ and $8 \mathrm{~h}$ after initiation of secondary simulation - elimination of chemotaxis control on swimming behaviour

both cases offshore of the front. The increased number of cells that reproduced in the region $\left(5.478 \times 10^{12}\right.$ $\left[4.453 \times 10^{12}\right]$ ) was explicable in terms of higher PAR and vertically averaged nutrient values in the shallower water, where the bulk of the population resided. When all 5 simulations were considered, it was clear that the postulated chemotaxis played a significant role in predicted frontal cell accumulation.

\section{SUMMARY AND CONCLUSIONS}

The Expanded Eulerian modeling approach was used to examine Karenia brevis bloom initiation. The physical model included an ocean of variable depth with a frontal region at the $25 \mathrm{~m}$ isobath. Nutrients were available from a surface source conceptually associated with outwelling from Florida bays and from a near bottom source conceptually associated with upwelling or sediment flux. The biological model included physiological rate processes, biochemical quotas, and behavioral responses based on cellular optimization and environmental conditions. The model was initialized with a fixed concentration of $1 \mathrm{cell} \mathrm{ml}^{-1}$ on the inflow portion (lowest $22 \mathrm{~m}$ ) of the water column at the $40 \mathrm{~m}$ isobath. The nutrient front under upwelling-favorable winds represented the site of cell concentrations, and trapped most cells when cells reached the $25 \mathrm{~m}$ isobath. The trapping mechanism 
was a combination of fluid advection and postulated swimming behavior - primarily chemotaxis - onshore of the front. Onshore of the front, cells swam upwards due to attraction to light or nutrients, were then advected offshore in the surface layer, swam downwards towards nutrients offshore of the front, and were finally advected back onshore in the bottom region. Comparison of the results of simulations with and without the offshore bottom nutrient source indicated that the presence of an offshore bottom nutrient source strongly enhances population development near the nutrient front.

Although the flow model assumed a constant eddy viscosity, basic physics indicated that for a 2-dimensional barotropic flow under upwelling-favorable winds, there would be offshore flow at the surface and onshore flow at depth, a key part of the trapping scenario. Any biological swimming model driven by chemotaxis would show similar trapping results.

The trapping scenario depended on the postulated ability of cells to follow a vertical nutrient gradient, and this remains to be tested experimentally.

Acknowledgements. This study was based on research supported in part by the NOAA 'Ecology and Oceanography of Harmful Algal Blooms' (ECOHAB) program through grant NA16OP1440, and by the USA Environmental Protection Agency's (EPA) 'Science to Achieve Results' (STAR) program through grant R-82937001. This work was not reviewed by NOAA or EPA, and therefore does not necessarily reflect their views and no official endorsement should be inferred. We thank anonymous reviewers for constructive comments that improved the manuscript.

\section{LITERATURE CITED}

Evens TJ, Kirkpatrick GJ, Millie DF, Chapman DJ, Schofield OME (2001) Photophysiological responses of the toxic red-tide dinoflagellate Gymnodinium breve (Dinophy-

Editorial responsibility: Otto Kinne (Editor-in-Chief), Oldendorf/Luhe, Germany ceae) under natural sunlight. J Plankton Res 23:1177-1194

Franks PJS (1992a) Sink or swim: accumulation of biomass at fronts. Mar Ecol Prog Ser 82:1-12

Franks PJS (1992b) Phytoplankton blooms at fronts: patterns, scales, and physical forcing mechanisms. Rev Aquat Sci 6: 121-137

Janowitz GS, Kamykowski D (1999) An Expanded Eulerian model of phytoplankton environmental response. Ecol Model 118:237-247

Kamykowski D, Milligan EJ, Reed RE (1998a) Biochemical relationships with orientation of the autotrophic dinoflagellate, Gymnodinium breve, under nutrient replete conditions. Mar Ecol Prog Ser 167:105-117

Kamykowski D, Milligan EJ, Reed RE (1998b) Relationships between taxis responses and diel vertical migration in autotrophic dinoflagellates. J Plankton Res 20:1781-1796

Liu G, Janowitz GS, Kamykowski D (2001a) A biophysical model of population dynamics of the autotrophic dinoflagellate Gymnodinium breve. Mar Ecol Prog Ser 210: $101-124$

Liu G, Janowitz GS, Kamykowski D (2001b) The influence of environmental nutrient condition on Gymnodinium breve (Dinophyceae) population dynamics: a numerical study. Mar Ecol Prog Ser 213:13-37

Liu G, Janowitz GS, Kamykowski D (2002) Influence of current shear on Gymnodinium breve (Dinophyceae) population dynamics. Mar Ecol Prog Ser 231:47-66

Sinclair GA ( 2005) Environmental and behavioral influences on Karenia brevis' nitrate uptake. MSc thesis, North Carolina State University, Raleigh

Tester PA, Steidinger KA (1997) Gymnodinium breve red tide blooms: initiation, transport and consequences of surface circulation. Limnol Oceanogr 42:1039-1051

Tomlinson MC, Stumpf RP, Ransibrahmanakul V, Truby EW, Kirkpatrick GJ, Pederson BA, Vargo GA, Heil CA (2004) Evaluation of the use of SeaWiFS imagery for detecting Karenia brevis harmful algal blooms in the eastern Gulf of Mexico. Remote Sens Environ 91:293-303

Walsh JJ, Haddad KD, Dieterle DA, Weisberg RH and 5 others (2002) A numerical analysis of landfall of the 1979 red tide of Karenia brevis along the west coast of Florida. Cont Shelf Res 22:15-38

Yang H, Weisberg R (1999) Response of West Florida Shelf circulation to climatological wind stress forcing. J Geophys Res 104:5301-5320

Submitted: February 7, 2005; Accepted: October 27, 2005 Proofs received from author(s): April 12, 2006 